\title{
First record of Philometra katsuwoni (Nematoda, Philometridae), a parasite of skipjack tuna Katsuwonus pelamis (Perciformes, Scombridae), off South American Atlantic Coast
}

\author{
Melissa Querido Cárdenas ${ }^{1,3}$, František Moravec ${ }^{2}$ \& Anna Kohn ${ }^{1}$ \\ ${ }^{1}$ Laboratório de Helmintos Parasitos de Peixes, Instituto Oswaldo Cruz, Fiocruz, \\ Av. Brasil, 4365, CEP 21045-900, Rio de Janeiro, RJ, Brazil \\ ${ }^{2}$ Institute of Parasitology, Biology Centre of the Academy of Sciences of the Czech Republic, \\ Branišovská 31, 370 05, České Budějovice, Czech Republic \\ ${ }^{3}$ Corresponding author: Melissa Querido Cárdenas, e-mail: melissaq@ioc.fiocruz.br
}

CÁRDENAS, M.Q., MORAVEC, F. \& KOHN, A. First record of Philometra katsuwoni (Nematoda, Philometridae), a parasite of skipjack tuna Katsuwonus pelamis (Perciformes, Scombridae), off South American Atlantic Coast. Biota Neotrop., 9(2): http://www.biotaneotropica.org.br/v9n2/en/abstract?shortcommunication+bn01809022009.

\begin{abstract}
The nematode Philometra katsuwoni Petter \& Baudin-Laurencin, 1986, a gonad-infecting parasite of Katsuwonus pelamis (Linneaus 1758), originally described from the Gulf of Guinea, is reported for the first time from the coastal zone of Rio de Janeiro State, Brazil. As compared with the original description, the males of the Brazilian material are generally somewhat larger and their right spicule and the gubernaculum are longer. The subgravid female is described for the first time. It is characterized by the anterior inflation of the esophagus and by the presence of two distinct caudal lobes.
\end{abstract}

Keywords: Brazil, fish parasite, nematode, helminth.

CÁRDENAS, M.Q., MORAVEC, F. \& KOHN, A. Primeiro registro de Philometra katsuwoni (Nematoda, Philometridae), parasitando Katsuwonus pelamis (Perciformes, Scombridae), ocorrentes ao largo da Costa Atlântica da América do Sul. Biota Neotrop., 9(2): http://www.biotaneotropica.org.br/v9n2/pt/abstract?shortcommunication+bn01809022009.

Resumo: Philometra katsuwoni Petter \& Baudin-Laurencin 1986, nematóide parasito do ovário de Katsuwonus pelamis (Linneaus 1758), originalmente descrito no Golfo da Guiné, é referido pela primeira vez na zona costeira do Estado do Rio de Janeiro, Brasil. Comparados com a descrição original, os machos do material brasileiro são um pouco maiores e possuem o espículo direito e o gubernáculo mais longos. A fêmea subgrávida é descrita pela primeira vez. Ela se caracteriza pela região anterior do esôfago inflada e pela presença de dois lobos caudais distintos.

Palavras-chave: Brasil, parasito de peixe, nematóide, helminto. 


\section{Introduction}

Species of Philometra Costa, 1845 (Dracunculoidea, Philometridae) infecting gonads of marine fishes are widely distributed in all oceans (Moravec 2006). Pathogenic effects of these parasites, such as sucking of blood, atrophy of developing ova, fibrosis of ovarian tissue, increasing numbers of granulocytes and haemorrhages (Moravec et al. 2002), may cause a serious damage to fish ovaries, affecting thus fish reproduction (Moravec et al. 2006, Moravec \& Salgado-Maldonado 2007). Some of these parasites are known to be agents of serious diseases of fish with economic importance. Therefore, especially with quickly developing cultures of marine fishes, the study of these nematodes is highly desirable.

During recent investigations into helminth parasites of the skipjack tuna, Katsuwonus pelamis L. (Perciformes, Scombridae), off the Atlantic coast of Brazil, specimens referable to the little-known philometrid species Philometra katsuwoni Petter \& Baudin-Laurencin, 1986 were found. Their subsequent study resulted in obtaining some new morphometrical data, which are presented herein.

\section{Material and Methods}

Helminth parasites of skipjack tuna $K$. pelamis obtained from the Atlantic Ocean, off Cabo Frio, State of Rio de Janeiro, Brazil ( $22^{\circ} 52^{\prime} 46^{\prime \prime} \mathrm{S}$ and $42^{\circ} 01^{\prime} 07^{\prime \prime} \mathrm{W}$ ) were investigated. The gonads were examined in separate Petri dishes containing $0.85 \% \mathrm{NaCl}$ solution. Nematodes were fixed with hot $70 \%$ ethanol GL. For light microscopy study, nematodes were cleared in 50\% phenol. Some specimens were preserved in Canada balsam and other material was maintained in vials in ethanol; specimens were deposited in the Helminthological Collection of the Oswaldo Cruz Institute (CHIOC). Photomicrographs were taken using a Nikon ${ }^{\circledR}$ Eclipse E800 micrographic system with a differential interference contrast (DIC) apparatus or a phase contrast system of Zeiss ${ }^{\circledR}$ Axiophot microscope. Measurements are in micrometers $(\mu \mathrm{m})$ unless otherwise indicated, quoted as the ranges with means in parentheses followed by the number of specimens measured (n).

\section{Results and Discussion}

\section{Philometra katsuwoni Petter \& Baudin-Laurencin, 1986}

Male (based on 7 specimens) (Figures 3-5, 11-14): Body filiform, whitish, very thin, with smooth cuticle. Body 8.64-17.13 (14.46) $\mathrm{mm}$ long $(\mathrm{n}=7)$ and $120-175(157)$ wide $(\mathrm{n}=7)$ at mid-portion of body. Cephalic end rounded. Mouth small, surrounded by indistinct cephalic papillae. Esophagus narrow, 950-1,850 (1,360) long $(n=6)$, with not well differentiated glandular region. Esophagus opens into intestine through distinct paired bilobed valve; ventriculus not observed. Nerve ring situated 163-315 (239) $(\mathrm{n}=2)$ from anterior extremity. Excretory pore located 315-375 (355) $(n=3)$ from anterior end of body,
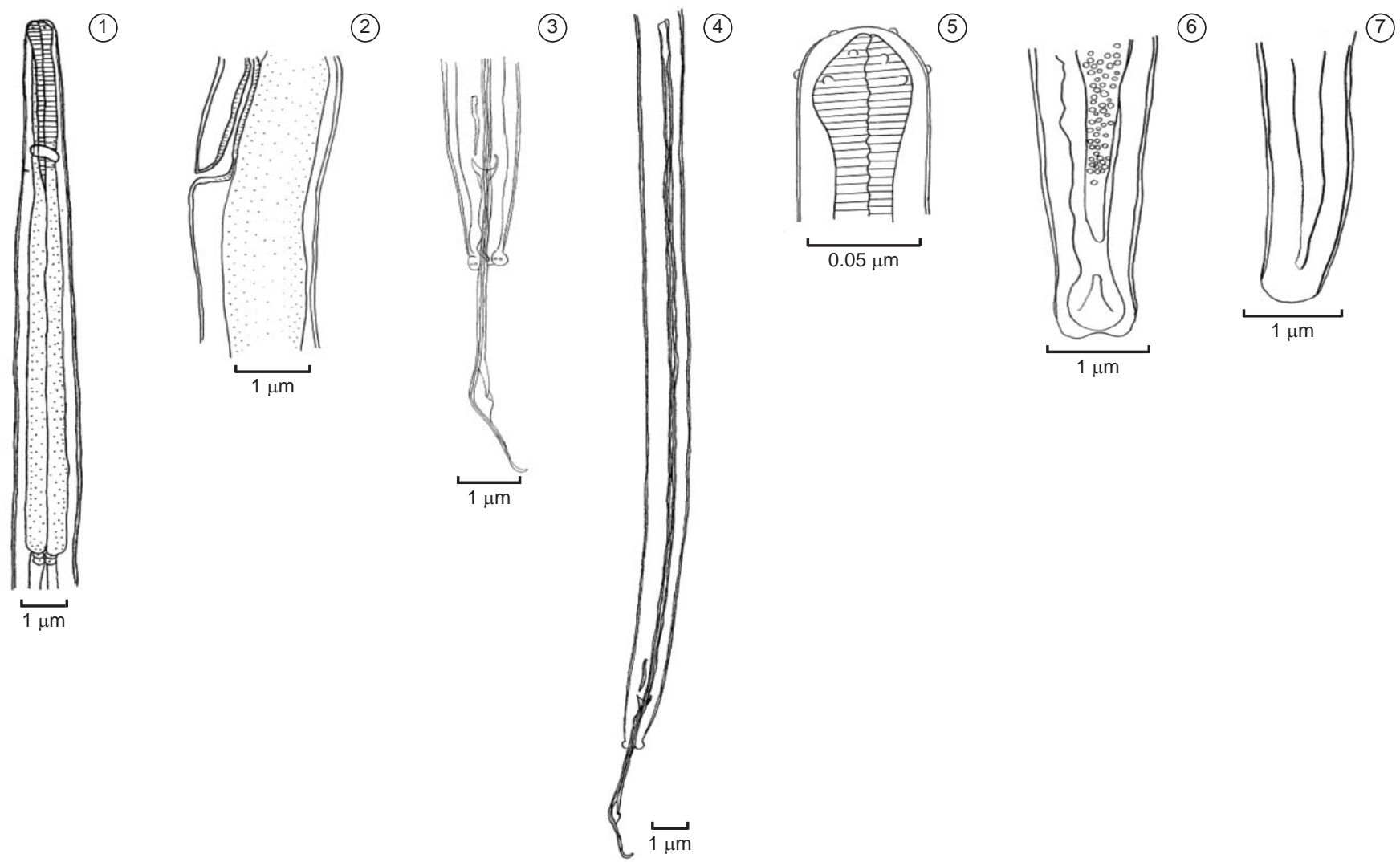

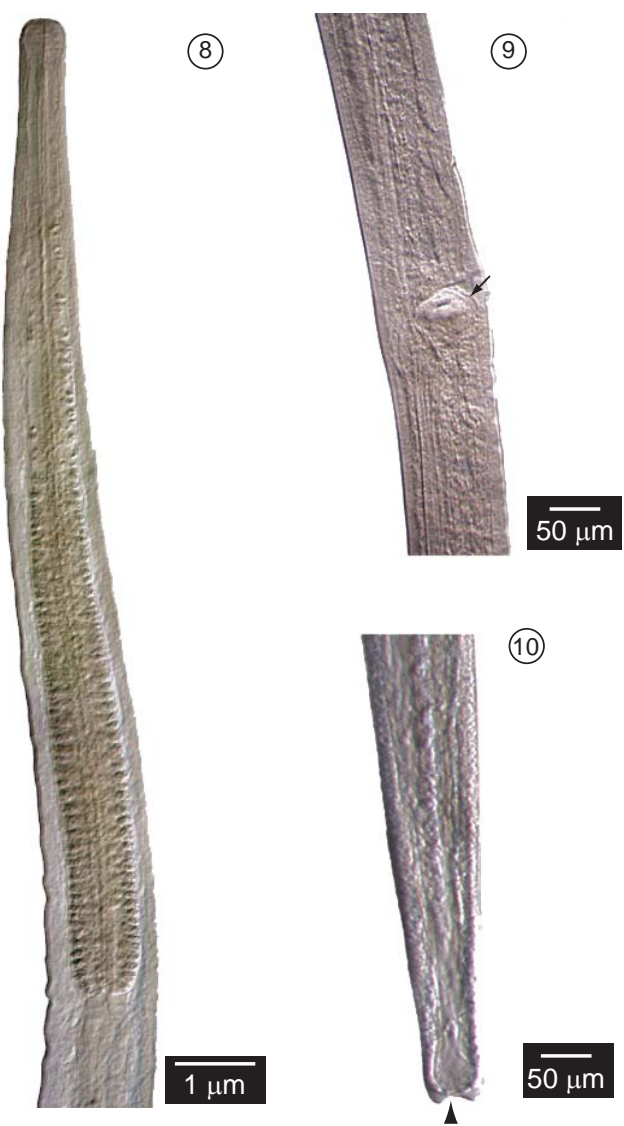

Figures 8-10. Female of Philometra katsuwoni observed by differential interference contrast (DIC). 8) Esophageal region of body. 9) Vulva (see arrow). 10) Ventral view of bilobed caudal end (arrowhead).

Figuras 8-10. Fêmea de Philometra katsuwoni observada por contraste diferencial interferencial (DIC). 8) Região esofagiana do corpo. 9) Vulva (ver seta). 10) Vista ventral mostrando a terminação bilobada da cauda (cabeça de seta). near nerve ring. Posterior end of body blunt, with two lobules (Figures 3, 4, 11, 13, 14). Each lobule contains two hardly visible papillae. Spicules narrow and unequal in length (Figure 4). Right spicule very long, measuring 2,150-2,570 $(2,330)(n=7)$, slender, needle-like, with membranous enlargement at posterior region and with pointed membranous distal tip (Figures 3, 4, 11, 12). Left spicule very short and less sclerotized, measuring 75-115 (97) in length $(n=5)$, with rugose surface (Figures 3, 4, 13, 14). Spicule length ratio 1:21-33 $(\mathrm{n}=5)$. Gubernaculum $150-163$ (152) long $(n=7)$, longer than shorter spicule; its anterior end curved (Figures 3, 13, 14).

Female (based on 5 subgravid specimens; 3 of them fragmented) (Figures 1-2, 6-10): Body filiform, whitish, very thin, with smooth cuticle; length 31.14-33.5 mm $(\mathrm{n}=2)$, width at mid-portion of body 125-160 $(n=2)$. Cephalic end rounded. Mouth small, surrounded by indistinct cephalic papillae. Total length of esophagus $1,225-1,400(n=4)$. Length of muscular and glandular regions of esophagus 365-550 $(\mathrm{n}=4)$ and 730-920 $(\mathrm{n}=4)$, respectively; in some specimens, division into two regions indistinct (Figures 1,8). Anterior end of esophagus with distinct bulbous inflation. Nerve ring situated 300-395 $(\mathrm{n}=3)$ from anterior extremity (Figures 1). Posterior end of body rounded in lateral view and bilobed in ventral view (Figures 6, 7, 10). Vulva situated $10 \mathrm{~mm}$ from posterior end in one specimen $33.5 \mathrm{~mm}$ long (Figures 2, 9).

Host: Katsuwonus pelamis L.

Site of infection: gonads.

Locality: Cabo Frio, State of Rio de Janeiro, Brazil (collected in October 2006).

Specimens deposited: CHIOC 37224 (slide); 35660 a-b (vials).

The morphology of specimens of the present material is, more or less, in agreement with the original description of Philometra katsuwoni provided by Petter \& Baudin-Laurencin (1986). However, the males (except for one) of the Brazilian material were generally distinctly larger (14-17 vs. $9.5-12 \mathrm{~mm}$ long); the right spicule (2.15-2.57 vs. $1.75-2.08 \mathrm{~mm})$ and the gubernaculum (150-163 vs. 130-145) were also longer but, on the contrary, the left spicule was of a similar length
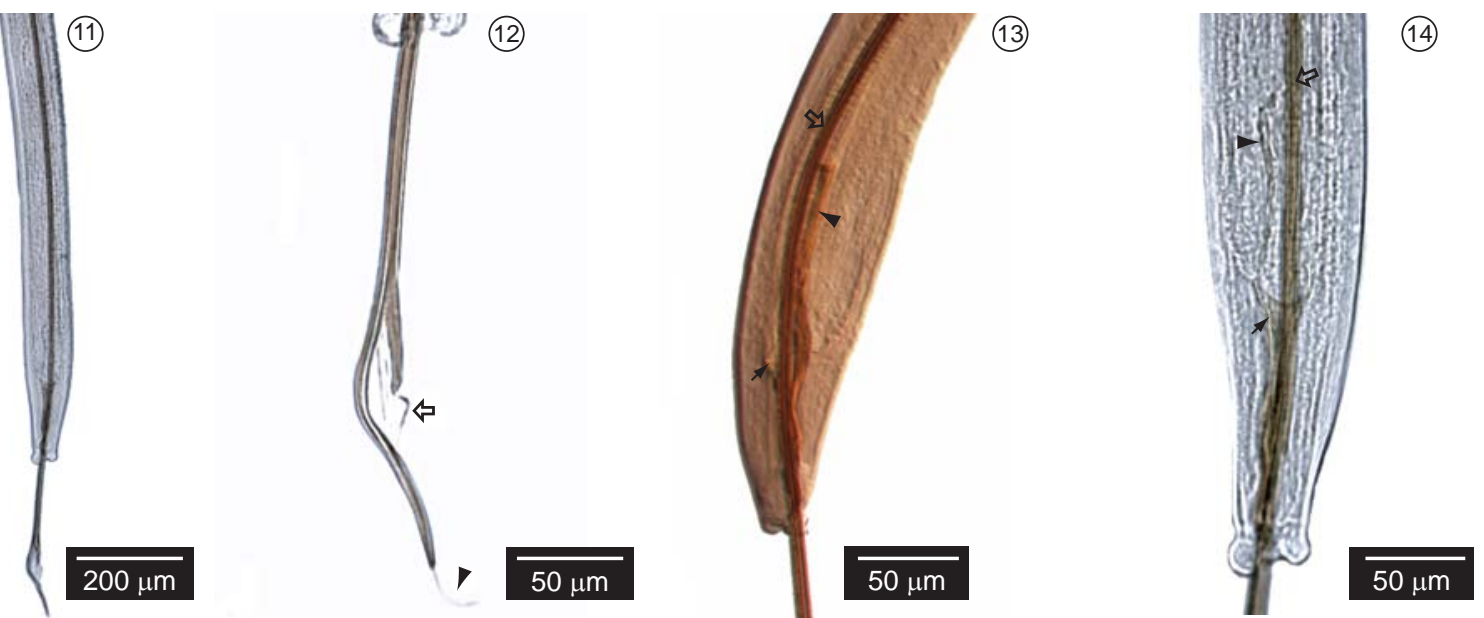

Figures 11-14. Philometra katsuwoni male. 11) Phase contrast of male posterior region. 12) Detail of right spicule indicating membranous enlargement at posterior region (large arrow) and pointed membranous distal tip (arrowhead). 13) Differential interference contrast (DIC) of posterior region of male showing right spicule (large arrow), left spicule (arrowhead) and gubernaculum (thin arrow). 14) Phase contrast of posterior region of male showing right spicule (large arrow), left spicule (arrowhead) and gubernaculum (thin arrow).

Figuras 11-14. Macho de Philometra katsuwoni. 11) Contraste de fase da região posterior do macho. 12) Detalhe do espículo direito indicando uma expansão membranosa na região posterior (seta larga) e uma ponta distal membranosa (cabeça de seta). 13) Contraste interferencial diferencial (DIC) da região posterior do macho mostrando o espículo direito (seta larga), o espículo esquerdo (cabeça de seta) e o gubernáculo (seta fina). 14) Contraste de fase da região posterior do macho mostrando o espículo direito (seta larga), o espículo esquerdo (cabeça de seta) e o gubernáculo (seta fina). 
(75-115 vs. 65-95). Petter \& Baudin-Laurencin (1986) had only body fragments of a juvenile female of $P$. katsuwoni at their disposal; they only mentioned that the cephalic structure was similar to that of the male and the posterior extremity was rounded, without any caudal projections. The morphology and measurements of conspecific subgravid females are provided for the first time in this paper. It shows that, as in the majority of Philometra spp., the female oesophagus of P. katsuwoni is bulbously inflated at its anterior end and the female posterior end is provided with two distinct lateral caudal lobes.

The authors are aware of the fact that the morphology of P. katsuwoni will require further study, because some taxonomically important features, such as the number and arrangement of cephalic papillae or the detailed structure of the male caudal end, can be properly studied only using scanning electron microscopy (Moravec 2006); this has not yet been used for this species. It will also be necessary to describe conspecific gravid (larvigerous) females and their larvae, whose body lengths are also important for the taxonomy of gonad-infecting philometrids. Moravec (2006) considered largesized (body length up to $95 \mathrm{~cm}$ ) gravid females of a Philometra sp. recorded from Katsuwonus pelamis of the Indian Ocean near the Maldives to possibly belong to P. katsuwoni.

Philometra katsuwoni was originally described from ovaries of K. pelamis from the Gulf of Guinea (Petter \& Baudin-Laurencin 1986) and was not recorded since. This is the second finding of this parasite and its first record off the Atlantic coast of Brazil and South America. The fauna of gonad-infecting philometrids remains poorly known in Brazil. The only two previous records are those by Crisp \& Klein (1973) reporting Philometra lateolabracis (Yamaguti, 1935) (=Philometra sp. - see Quiazon et al. 2008) from Haemulon plumierii (Lacépède) and Rego et al. (1983) reporting Philometra sp. (=probably P. saltarix Ramachandran, 1973) from Pomatomus saltatrix (Linnaeus).

\section{Acknowledgements}

The authors are grateful to Dra. Márcia Justo and Mariana Lopes, Instituto Oswaldo Cruz, Fiocruz, for help in collecting the nematodes; to Drs. Marcelo Knoff and Rodrigo Méxas, Instituto Oswaldo Cruz, Fiocruz for technical assistance regarding the photomicrographies.

\section{References}

CRISP, D.J. \& KLEIN, V.L.M. 1973. Contribution to the knowledge of Philometra lateolabracis Yamaguti, 1935 (Nematoda: Filarioidea). Mem. Inst. Oswaldo Cruz, 71(4): 481-483.

MORAVEC, F. 2006. Dracunculoid and anguillicoloid nematodes parasitic in vertebrates. Academia, Prague.

MORAVEC, F., DE BURON, I. \& ROUMILLAT, W.A. 2006. Two new species of Philometra (Nematoda: Philometridae) parasitic in the perciform fish Cynoscion nebulosus (Sciaenidae) in the estuaries of South Carolina, USA. Folia Parasitol. 53(1): 63-70.

MORAVEC, F., OGAWA, K., SUZUKI, M., MIYAZAKI, K. \& DONAI, H. 2002. On two species of Philometra (Nematoda, Philometridae) from the serranid fish Epinephelus septemfasciatus in Japan. Acta Parasitol. 47(1):34-40.

MORAVEC, F. \& SALGADO-MALDONADO, G. 2007. A new species of Philometra (Nematoda, Philometridae) from the gonads of the rock hind Epinephelus adscensionis (Osteichthyes) from the southern Gulf of Mexico. Acta Parasitol. 52(4):376-381.

PETTER, A.J. \& BAUDIN-LAURENCIN, F. 1986. Deux espèces du genre Philometra (Nematoda, Dracunculoidea) parasites de thons. Bull. Mus. Nat. Hist. Nat. 8(4):769-775.

QUIAZON, K.M., YOSHINAGA, T. \& OGAWA, K. 2008. Taxonomical study into two new species of Philometra (Nematoda: Philometridae) previously identified as Philometra lateolabracis (Yamaguti, 1935). Folia Parasitol. 55(1):29-41.

REGO, A.A., VICENTE, J.J., SANTOS, C.P. \& WEKID, R.M. 1983. Parasitas de anchovas, Pomatomus saltatrix (L.) do Rio de Janeiro. Cienc. Cult. 35(9):1329-1336. 